\title{
Potent activation of multiple signalling pathways by C-peptide in opossum kidney proximal tubular cells
}

\author{
N. M. Al-Rasheed ${ }^{1,3}$ • F. Meakin ${ }^{1}$ - E. L. Royal ${ }^{1}$ A. J. Lewington ${ }^{1,2} \cdot$ J. Brown ${ }^{2}$ G. B. Willars ${ }^{1}$ \\ N. J. Brunskill1, 2 \\ ${ }^{1}$ Department of Cell Physiology and Pharmacology, Faculty of Medicine and Biological Sciences, University of Leicester, \\ Leicester, United Kingdom \\ ${ }^{2}$ Department of Nephrology, Faculty of Medicine and Biological Sciences, University of Leicester, Leicester, UK \\ ${ }^{3}$ Department of Pharmacology, King Saud University, Riyadh, Saudi Arabia
}

\section{Abstract}

Aims/hypothesis. Proinsulin C-peptide is generally believed to be inert without any appreciable biological functions. However, it has been shown to modulate a variety of cellular processes important in the pathophysiology of diabetic complications. We therefore investigated the ability of C-peptide to stimulate intracellular signalling pathways in kidney proximal tubular cells, the altered activation of which may possibly be related to the development of diabetic nephropathy. Methods. Extracellular signal-regulated kinase (ERK) and Akt phosphorylation were evaluated by western blotting. ERK activity was measured by in vitro kinase assay. Intracellular $\mathrm{Ca}^{2+}$ was evaluated by confocal imaging. The membrane and cytosol-associated fractions of protein kinase $\mathrm{C}$ (PKC) isoforms were evaluated by western blotting. Proliferation was assessed by thymidine incorporation assay.

Results. Using the opossum proximal tubular kidney cell line as a model, we demonstrated that at high picomolar to low nanomolar concentrations, C-peptide stimulates extracellular signal-regulated mitogen-activated kinase $(3.3 \pm 0.1$-fold over basal at 3 minutes) and phosphatidylinositol 3-kinase $(4.1 \pm 0.05$-fold over basal at 5 minutes). ERK activation was attenuated by pre-treatment with a PKC inhibitor and abolished by pertussis toxin. Elevations of intracellular $\left[\mathrm{Ca}^{2+}\right]$ are seen in response to $5 \mathrm{nmol} / \mathrm{l} \mathrm{C}$-peptide with consequent activation of PKC- $\alpha$. Pre-treatment with pertussis toxin abolished PKC- $\alpha$. C-peptide is also a functional mitogen in this cell type, stimulating significantly increased cell proliferation. Proliferation was attenuated by wortmannin and pertussis toxin pretreatments. None of these effects is reproduced by scrambled C-peptide.

Conclusions/interpretation. This study provides evidence that C-peptide, within physiological concentration ranges, stimulates many signalling pathways in opossum kidney cells.

Keywords Calcium - C-peptide .

Diabetic nephropathy $\cdot$ Kidney $\cdot$ MAP kinase $\cdot$

Mitogen · PI 3-kinase · PKC
Received: 30 October 2003 / Accepted: 26 January 2004

Published online: 26 May 2004

(C) Springer-Verlag 2004

N. J. Brunskill $(\bullet)$

Department of Cell Physiology and Pharmacology,

Faculty of Medicine and Biological Sciences,

University of Leicester, Medical Sciences Building,

University Road, Leicester, LE1 9HN, United Kingdom

E-mail: njb18@le.ac.uk

Tel.: +44-116-2588043, Fax: +44-116-2525045

Abbreviations: Akt/PKB, protein kinase B .

DTT, dithiothreitol - ERK, extracellular signal-regulated

kinase · GPCR, G-protein coupled receptor ·

MAPK, mitogen-activated protein kinase $\cdot \mathrm{OK}$, opossum

\section{Introduction}

Proinsulin connecting peptide (C-peptide) is an enzymatic cleavage product derived from proinsulin during the biosynthesis of insulin [1]. Insulin and C-peptide are stored together within the secretory granules of pancreatic beta cells, being eventually released simultaneously and in equimolar amounts into the portal circulation [2]. C-peptide forms a linker between the

kidney $\cdot$ PI3-K, phosphoinositide 3-kinase $\cdot \mathrm{PKC}$, protein kinase C P PMA, phorbol myristate acetate .

PMSF, phenylmethansulfonylfluoride $\cdot$ PTC, proximal tubular cells $\cdot$ PTX, pertussis toxin 
A and B chains of insulin, facilitating correct folding and thus the establishment of disulfide bonds between adjacent cysteine residues [3]. Early after the discovery of C-peptide, workers attempted to delineate a role for C-peptide in the regulation of glucose homeostasis $[4,5,6]$. No such role could be found, encouraging the traditional belief that C-peptide is a biologically inert molecule.

Accumulating evidence, however, has begun to challenge this view by suggesting that $\mathrm{C}$-peptide plays a role in experimental and clinical diabetes. The infusion of C-peptide into patients with Type 1 diabetes over the short term (hours), in addition to the administration of insulin, ameliorates a variety of associated renal functional abnormalities [7]. Similarly, the more prolonged administration of C-peptide (months) is associated not only with improved renal function, but also enhanced autonomic and sensory nerve function $[8,9,10,11]$. Characteristic myocardial perfusion and limb blood flow changes observed in patients with Type 1 diabetes are also reversed by C-peptide [11, 12]. No effects of C-peptide infusion on any of these parameters have ever been demonstrated in healthy non-diabetic control subjects $[8,9,10,11]$.

At the cellular level various effects of C-peptide have now been described. Activation of $\mathrm{Na}^{+} / \mathrm{K}^{+}$ ATPase occurs in numerous nephron segments in response to $\mathrm{C}$-peptide stimulation, together with increased intracellular $\mathrm{Ca}^{2+}$ concentrations $\left(\left[\mathrm{Ca}^{2+}\right]_{\mathrm{i}}\right)$ in proximal tubular cells $[13,14,15,16]$. Recently Kitamura et al. [17] demonstrated C-peptide-mediated stimulation of a kinase cascade in Swiss 3T3 fibroblasts involving mitogen-activated protein kinases (MAPK), protein kinase $\mathrm{C}$ (PKC) and phosphoinositide-3-kinase (PI3-K). Specific cell membrane binding sites for C-peptide have recently been identified in renal tubular cells, skin fibroblasts and saphenous vein endothelial cells. Abolition of this binding by pertussis toxin (PTX) was observed, suggesting the involvement of a G-protein coupled receptor (GPCR). The calculated association rate constant $\left(\mathrm{K}_{\text {ass }}\right)$ of this receptor was about $3 \mathrm{nmol} / \mathrm{l}$, which suggests that under normal physiological conditions it is probably fully occupied, possibly explaining the absence of C-peptide effects in normal subjects [18, 19].

Diabetic nephropathy remains a serious complication of diabetes, and is characterised initially by renal growth. Hypertrophy of glomerular and tubular cells is prominent, together with thickening of basement membranes, but hyperplasia does not occur [20, 21, 22]. Later, matrix components accumulate in the glomerulus and tubulo-interstitium with progressive sclerosis. Tubular atrophy with almost complete loss of proximal tubular cells (PTC) is evident, a clear sign of major disturbances in growth and survival of this cell type. Interestingly, the pathogenesis of nephropathy does not seem to be substantially different in Type 1 and Type 2 diabetes [23, 24, 25].
Much attention has been given to signal transduction pathways activated in response to the persistent homeostatic disturbances in diabetes that may initiate and/or propagate diabetic renal pathophysiology. Activation of PKC in the kidney occurs within days of the onset of experimental diabetes [26], and this may in turn stimulate phospholipase A2, leading to the release of membrane-bound arachidonate [26, 27]. Another consequence of renal PKC activation is stimulation of MAPK [28]. The activation of MAPK in glomeruli obtained from rats with streptozotocin-induced diabetes and in mesangial cells grown in high glucose concentrations is mediated by PKC and contributes crucially to cell hypertrophy [29].

The precise role of C-peptide, or the lack thereof, in the modulation of these signalling pathways in diabetes and in the pathogenesis of diabetic nephropathy remains uncertain. Therefore, in view of our long-standing interest in renal tubular disease and the body of literature supporting a physiological role for C-peptide, we examined signalling and functional roles for C-peptide in the kidney. Our primary aim was to determine whether C-peptide has the capacity to signal in PTC, focusing especially on pathways involved in cell growth and the potential development of diabetic nephropathy. We used opossum kidney $(\mathrm{OK})$ cells, an immortalised kidney PTC cell line [30] that retains many characteristics of the proximal tubule [31]. Many typical proximal tubular functions such as parathyroid hormone responses and endocytic uptake of proteins have been investigated using this cell type $[32,33]$.

\section{Materials and methods}

Materials. Human 31 amino acid (aa) C-peptide and a 31 aa scrambled C-peptide were generously provided by Dr J. Wahren (Karolinska Institute, Stockholm, Sweden). These peptides were prepared as $250 \mu \mathrm{mol} / \mathrm{l}$ stock solutions in $50 \mathrm{mmol} / \mathrm{l}$ glacial acetic acid, and stored at $-20{ }^{\circ} \mathrm{C}$. All tissue culture media and plasticware were from Invitrogen Life Technologies (Paisley, UK) and general laboratory chemicals were from Sigma (Poole, UK) unless otherwise stated. Wortmannin, PTX and Ro-31-8220 were from Calbiochem (Nottingham, UK). The extracellular signal-regulated MAP kinase (ERK) substrate, a peptide (RRELVEPLTPSGEAPNQALLR) derived from the cytoplasmic tail of the epidermal growth factor receptor, was synthesised by the Protein and Nucleic Acid Chemistry Laboratory (University of Leicester, UK). Rabbit polyclonal anti-ERK-1 and antiphospho-ERK1/2 were obtained from Santa Cruz Biotechnology (Santa Cruz, Calif., USA). Sheep monoclonal anti-Akt1/PKB $\alpha$ and anti-phospo-Akt1/PKB $\alpha$ were from Upstate Biotechnology (Milton Keynes, UK). Anti-PKC isoforms were from Transduction Laboratories (San Diego, Calif., USA). Protein A sepharose CL-4B was from Pharmacia Biotech (Uppsala, Sweden). We obtained $\gamma-\left[{ }^{32} \mathrm{P}\right]$ ATP from Perkin Elmer Life Sciences (Cambridge, UK) and $\left[{ }^{3} \mathrm{H}\right]$-thymidine from Amersham Biosciences (Chalfont St. Giles, Buckinghamshire, UK).

Cell culture. Opossum kidney cells were obtained from Dr J. Caverzasio (University Hospital, Geneva, Switzerland) and used between passages 72-87. Cells were maintained in 
Dulbecco's modified Eagle's media-Ham's mix (DMEM-F12), supplemented with $10 \%$ FCS, 2 mmol/l L-glutamine, $100 \mathrm{U} / \mathrm{ml}$ penicillin, $100 \mu \mathrm{g} / \mathrm{ml}$ streptomycin and $10 \mathrm{mmol} / \mathrm{l} \mathrm{HEPES}$. In all experiments cells were serum-starved overnight before being subject to agonist stimulation to ensure as far as possible that cells were not exposed to mitogenic agents or C-peptide derived from FCS.

Determination of ERK and Akt activation by western blotting of phospho-ERK and phospho-Akt. Cells growing in 6-well plates were stimulated with various concentrations of C-peptide or scrambled peptide in serum-free DMEM-F12 for various times. After stimulation, cells were rinsed with ice-cold PBS and then lysed in Laemmli buffer $(60 \mathrm{mmol} / \mathrm{l}$ Tris, $\mathrm{pH}$ 6.8, 10\% glycerol, $2 \%$ SDS, $100 \mathrm{mmol} / \mathrm{l}$ dithiothreitol [DTT] and $0.01 \%$ bromophenol blue). Samples were separated by SDS-PAGE and then transferred to nitrocellulose membranes. Membranes were blocked with a $5 \%(\mathrm{w} / \mathrm{v})$ solution of dried milk powder in TTBS $(20 \mathrm{mmol} / \mathrm{l}$ Tris base, $100 \mathrm{mmol} / \mathrm{l}$ $\mathrm{NaCl}$ and $0.05 \%$ Tween 20, pH 7.5) and immunoblotted using antisera against phosphorylated ERK or phosphorylated Akt. To check the uniformity of loading, blots were stripped and re-probed with antisera to total (phospho- and non-phospho ERK-1) ERK or total Akt. In all cases, primary antibodies were visualised using peroxidase-conjugated secondary antibodies and enhanced chemiluminescence (Amersham). Immunoblots were quantitated using Scion Image analysis software (version 4.0.2; Scion, Frederick, Md., USA).

Determination of ERK activity by in vitro kinase assay. ERK activity in OK cells after treatment with test agents was measured using an in vitro kinase assay, in essence as previously described [34]. Briefly, confluent monolayers of OK cells were grown in 6-well plates. After stimulation, the cells were washed once with ice-cold PBS and then solubilised with icecold lysis buffer $(20 \mathrm{mmol} / \mathrm{l}$ Tris- $\mathrm{HCl}, \mathrm{pH} 8.0,0.5 \%$ Nonidet P-40, $250 \mathrm{mmol} / \mathrm{l} \mathrm{NaCl}, 3 \mathrm{mmol} / \mathrm{l}$ EDTA, $3 \mathrm{mmol} / \mathrm{l}$ EGTA, $1 \mathrm{mmol} / \mathrm{l}$ phenylmethansulfonylfluoride [PMSF], $2 \mathrm{mmol} / \mathrm{l}$ $\mathrm{Na}_{3} \mathrm{VO}_{4}$ and $1 \mathrm{mmol} / \mathrm{l}$ DTT). The lysates were clarified by 10 minutes of centrifugation at $14000 \mathrm{~g}$ at $4{ }^{\circ} \mathrm{C}$. Next rabbit polyclonal anti-ERK-1 antiserum (stock concentration $200 \mu \mathrm{g} / \mathrm{ml}$ ) was added to give a final concentration of $2 \mu \mathrm{g} / \mathrm{ml}$, and incubated for $120 \mathrm{~min}$ on ice. Immune complexes were incubated for $30 \mathrm{~min}$ at $4{ }^{\circ} \mathrm{C}$ with $100 \mu \mathrm{l}$ of a $15 \%(\mathrm{v} / \mathrm{v})$ slurry of protein A-sepharose. Immunoprecipitates were then washed twice in $200 \mu \mathrm{l}$ lysis buffer and twice in $200 \mu \mathrm{l}$ kinase buffer (20 mmol/l HEPES, pH 7.2, $20 \mathrm{mmol} / 1 \quad \beta$-glycerophosphate, $10 \mathrm{mmol} / \mathrm{l} \mathrm{MgCl}_{2}, 1 \mathrm{mmol} / \mathrm{l}$ DTT and $\left.50 \mu \mathrm{mol} / \mathrm{l} \mathrm{Na}_{3} \mathrm{VO}_{4}\right)$. An aliquot of $40 \mu \mathrm{l}$ kinase buffer containing $20 \mu \mathrm{mol} / 1 \gamma\left[{ }^{32} \mathrm{P}\right]$-ATP $(92.5 \mathrm{kBq} / \mathrm{nmol})$ and $200 \mu \mathrm{mol} / \mathrm{l}$ of synthetic ERK peptide substrate was added to immunoprecipitates to initiate the kinase reaction. The reactions were terminated after 20 minutes by adding $10 \mu \mathrm{l}$ of $25 \%(\mathrm{w} / \mathrm{v})$ trichloroacetic acid. The mixtures were then centrifuged at $14000 \mathrm{~g}$ for $2 \mathrm{~min}$ and $40 \mu \mathrm{l}$ of the supernatant spotted on to squares of P81 cation exchange paper (Whatman, Maidstone, UK). Papers were washed three times for $5 \mathrm{~min}$ in $0.5 \%(\mathrm{v} / \mathrm{v})$ orthophosphoric acid, rinsed once with acetone and air-dried, after which radioactivity was determined by liquid scintillation counting.

Confocal imaging of $\left[\mathrm{Ca}^{2+}\right]_{i}$. OK cells were plated on to sterile 25-mm diameter poly-D-lysine-coated glass cover slips and allowed to adhere for $24 \mathrm{~h}$. Cells were incubated in Krebs buffer (10 mmol/l HEPES, $4.2 \mathrm{nmol} / \mathrm{l} \mathrm{NaHCO}$, $11.7 \mathrm{mmol} / \mathrm{l}$ D-glucose, $1.18 \mathrm{mmol} / \mathrm{l} \mathrm{MgSO} \cdot 7 \mathrm{H}_{2} \mathrm{O}, 1.18 \mathrm{mmol} / 1 \mathrm{KH}_{2} \mathrm{PO}_{4}$, $4.69 \mathrm{mmol} / \mathrm{l} \mathrm{KCl}, 118 \mathrm{mmol} / \mathrm{l} \mathrm{NaCl}, 1.29 \mathrm{mmol} / \mathrm{l} \mathrm{CaCl}{ }_{2} \cdot 2 \mathrm{H}_{2} \mathrm{O}$, $\mathrm{pH}$ 7.4) containing $6 \mu \mathrm{mol} / \mathrm{l}$ fluo-3-acetoxymethyl ester (fluo-
3-AM, Molecular Probes, Cambridge, UK). This was done at room temperature for 45 to $90 \mathrm{~min}$. Cover slips were then mounted in a chamber on a heated stage of an Olympus $1 x$ 70-SIF inverted microscope. The chamber was perfused with Krebs buffer (bath temperature $37{ }^{\circ} \mathrm{C}$ ), with or without $\mathrm{C}$-peptide or scrambled C-peptide, at $5 \mathrm{ml}$ per minute. The intracellular fluorescence, as an index of $\left[\mathrm{Ca}^{2+}\right]_{\mathrm{i}}$, was determined by using an Ultraview confocal imaging system (Perkin Elmer). Cells were excited with a krypton/argon laser at $488 \mathrm{~nm}$ and emitted light was collected above $510 \mathrm{~nm}$ with a narrow-band pass filter.

Determination of PKC activation by translocation assay. The cytosol to membrane translocation of $\mathrm{PKC} \alpha$ was determined by cell fractionation and western blotting as an index of activation as previously described [35]. Cells were stimulated and then lysed in $200 \mu \mathrm{l}$ ice-cold lysis buffer $(20 \mathrm{mmol} / \mathrm{l}$ Tris- $\mathrm{HCl}$, $5 \mathrm{mmol} / \mathrm{l}$ EGTA, $2 \mathrm{mmol} / \mathrm{l}$ EDTA, $1 \mathrm{mmol} / \mathrm{l} \mathrm{DTT}, 0.5 \mathrm{mmol} / \mathrm{l}$ PMSF, $10 \mu \mathrm{mol} / 1$ iodoacetamide, $\mathrm{pH}$ 7.4) and incubated on ice for $30 \mathrm{~min}$. Samples were then centrifuged (20800 g, $15 \mathrm{~min}$, $4{ }^{\circ} \mathrm{C}$ ) to separate cytosolic and membrane fractions. A $100 \mu \mathrm{l}$ aliquot of supernatant (cytosolic fraction) was removed. The remaining supernatant was aspirated and the membrane pellet re-suspended in $200 \mu \mathrm{l}$ volume of solubilisation buffer (9.2 mmol/l Tris, $0.92 \mathrm{mmol} / \mathrm{l}$ EGTA, $150 \mathrm{mmol} / \mathrm{l} \mathrm{NaCl}, 0.1 \%$ [v/v] SDS, $1 \%$ [v/v] ethylphenylpolyethylene glycol [Nonidet P-40], 0.5\% [w/v] deoxycholate, $0.5 \mathrm{mmol} / 1 \mathrm{PMSF}, 10 \mu \mathrm{mol} / \mathrm{l}$ benzamidine hydrochloride and $5 \mu \mathrm{mol} / \mathrm{l}$ iodoacetamide, $\mathrm{pH}$ 7.4). An equal volume of sample buffer (100 mmol/l Tris, $2 \%$ SDS, $0.1 \%$ bromophenol blue, $10 \%$ [v/v] glycerol, $200 \mathrm{mmol} / \mathrm{l}$ DTT) was added to the membrane and cytosolic fractions. Proteins were separated by SDS-PAGE, transferred to nitrocellulose and immunoblotted for PKC $\alpha, \varepsilon$ and $\imath$ as described above, using anti PKC $\alpha, \varepsilon$ and $\mathrm{l}$ at $0.1,0.5$ and $0.5 \mu \mathrm{g} / \mathrm{ml}$ respectively. The nitrocellulose was subsequently stained using Ponceau-s (0.2\% Ponceau-S and 3\% TCA) to ensure equivalent protein loading and transfer.

Incorporation of $\left[{ }^{3} \mathrm{H}\right]$-thymidine. Proliferation of $\mathrm{OK}$ cells in response to $\mathrm{C}$-peptide was assessed by $\left[{ }^{3} \mathrm{H}\right]$-thymidine incorporation. Cells were plated in 24-well plates and grown to approximately $80 \%$ confluence. Serum-starved cells were exposed to various concentrations of C-peptide, $10 \%$ fetal calf serum or serum-free media as a control. After $22 \mathrm{~h}$ of incubation at $37{ }^{\circ} \mathrm{C}$, the culture medium was replaced with serumfree medium containing $37 \mathrm{kBq}$ of $\left[{ }^{3} \mathrm{H}\right]$-thymidine. After a further $2 \mathrm{~h}$ of incubation, cells were washed with ice-cold PBS and fixed at $4^{\circ} \mathrm{C}$ in $50 \%$ methanol and $10 \%$ glacial acetic acid for $30 \mathrm{~min}$, and then in $10 \%$ trichloroacetic acid for $10 \mathrm{~min}$. Cells were then solubilised overnight in $100 \mathrm{mmol} / \mathrm{l} \mathrm{NaCl}$ containing $0.1 \%$ SDS, after which $\left[{ }^{3} \mathrm{H}\right]$-thymidine incorporation was determined by standard liquid scintillation counting.

Data presentation and analysis. Data are presented as means \pm SEM. Statistical analysis was by unpaired Student's $t$ test for comparison between two experimental groups. For multiple comparisons, one-way ANOVA with Tukey's correction was used. Differences were considered significant at a $p$ value of less than 0.05 .

\section{Results}

Effect of C-peptide on activation of ERK-1 and -2. Incubation of OK cells with $\mathrm{C}$-peptide resulted in a time- and a concentration-dependent increase in phos- 
a

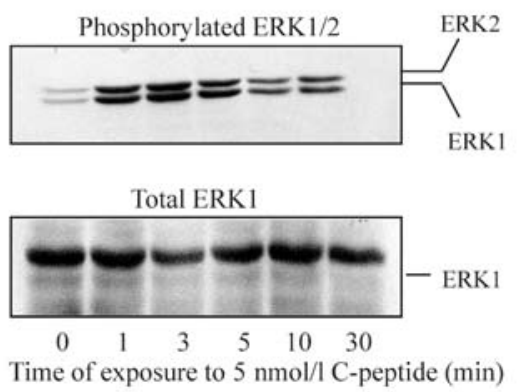

b

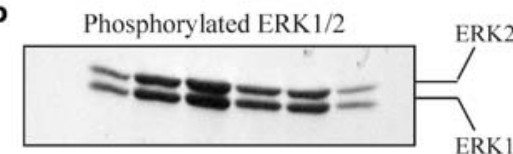

Total ERK1

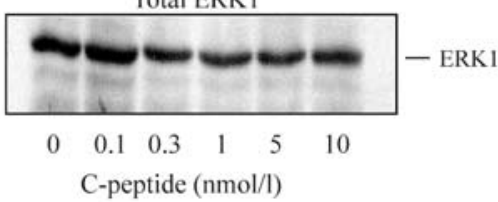

c
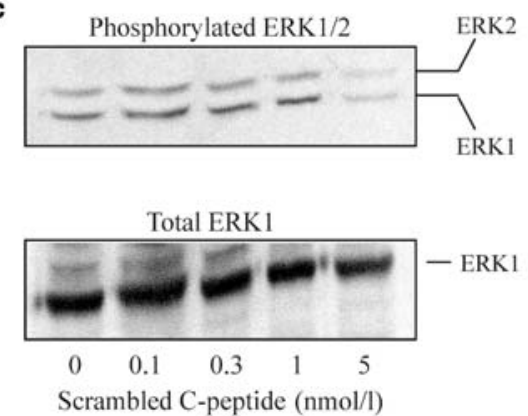

Fig. 1. Stimulation of ERK phosphorylation by C-peptide but not scrambled C-peptide in opossum kidney cells. a. Time course of activation. Cells were treated with $5 \mathrm{nmol} / \mathrm{l} \mathrm{C}$-peptide for the indicated times and total extracellular signal-regulated kinase (ERK) or phosphorylated ERK were detected by immunoblotting. The left panel shows a representative blot. Phosphorylated bands were quantified and values expressed graphically (right panel). $* * p<0.01, * * * p<0.001$, relative to 0 minutes. b. Concentration-response of activation. Cells were treated with the indicated concentrations of C-peptide for 5 min and total ERK or phosphorylated ERK were detected by immunoblotting. The left panel shows a representative blot. Phosphorylated bands were quantified and values expressed graphically (right panel). $* p<0.05, * * * p<0.001$, relative to control time. c. Effect of scrambled C-peptide on ERK phosphorylation in opossum kidney cells. Cells were treated with the indicated concentrations of scrambled C-peptide for $5 \mathrm{~min}$ and total ERK or phosphorylated ERK were detected by immunoblotting. A representative blot is shown. Within the graphs (a, b) data are means \pm SEM, $n=3$. Triangles represent total ERK, squares represent phosphorylated ERK1, and circles represent phosphorylated ERK2
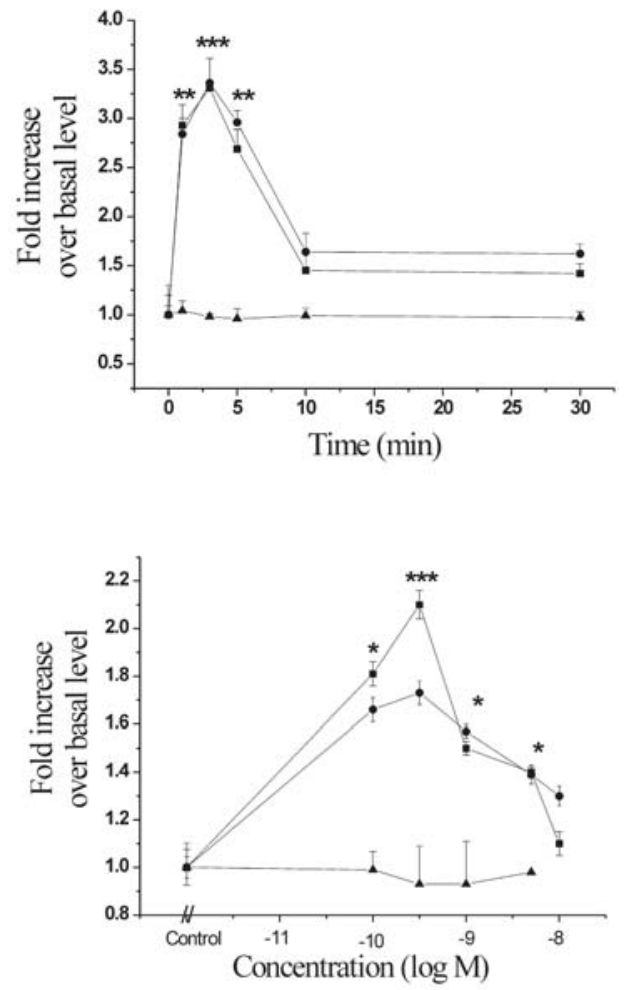

phorylated ERK (Fig. 1). Phosphorylated ERK appeared rapidly after stimulation, displaying a peak and plateau. A maximal stimulation of 3.3 \pm 0.1 -fold over basal occurred at $3 \mathrm{~min}$, which fell to a plateau between 10 and $30 \mathrm{~min}$. Phosphorylation of ERK increased 1.8 \pm 0.1 -fold over the basal at C-peptide concentrations as low as $100 \mathrm{pmol} / \mathrm{l}$, with maximal stimulation of 2.1 \pm 0.1 -fold over basal occurring at $300 \mathrm{pmol} / \mathrm{l}$. The phosphorylation of ERK-1 and -2 decreased progressively with concentrations of C-peptide above $300 \mathrm{pmol} / \mathrm{l}$. Loading controls using total ERK-1 antisera demonstrated equivalent protein loading between lanes. Scrambled C-peptide did not affect phosphorylation of ERK-1 or ERK-2 (Fig. 1c).

To confirm that C-peptide activated ERK in OK cells, we also examined ERK activity by immune complex in vitro kinase assay, using a synthetic peptide that corresponds to a portion of epidermal growth factor receptor as substrate. Figure 2 shows a concentration-dependent stimulation of ERK activity in response to $\mathrm{C}$-peptide for $5 \mathrm{~min}$. The concentration 
a
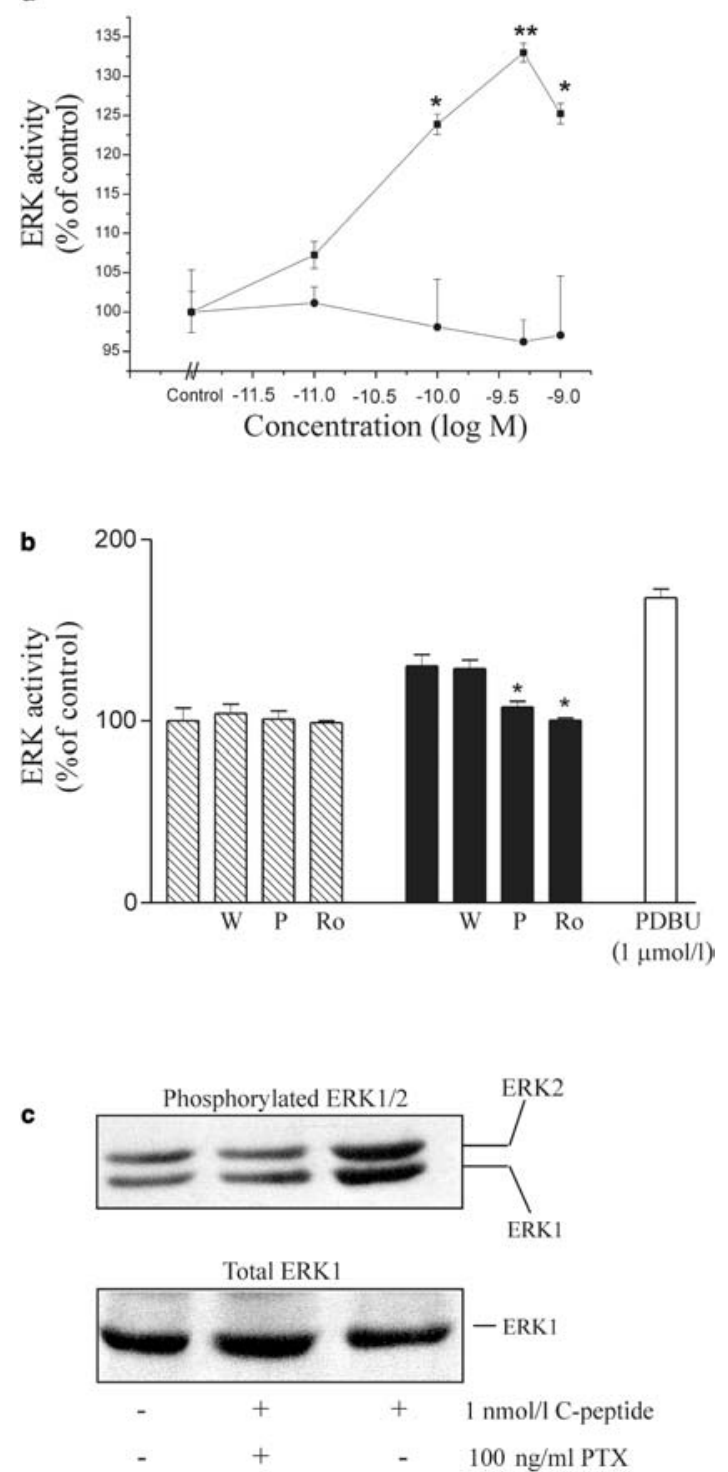

Fig. 2. Stimulation of extracellular signal-regulated kinase (ERK) activity by C-peptide but not scrambled C-peptide in opossum kidney cells. Activity was measured by in vitro kinase assay. a. Opossum kidney (OK) cells were treated with the indicated concentrations of C-peptide (squares) or scrambled C-peptide (circles) for 5 minutes and ERK activity measured. Results are percentages \pm SEM $(n=3)$ of negative control cells that were incubated with serum-free media. $* p<0.05, * * p<0.01$, relative to controls. b. Effects of pertussis toxin (P), Ro-31-8220 (Ro) and wortmannin (W) on basal (hatched bars) and C-peptide-induced (black bars) ERK activity in OK cells. Unlabelled bars represent basal or C-peptide-induced ERK activity in the absence of inhibitors. OK cells were pre-treated with $100 \mathrm{ng} / \mathrm{ml}$ pertussis toxin for $18 \mathrm{~h}$ or with Ro-31-8220 $(10 \mu \mathrm{mol} / \mathrm{l})$ for $30 \mathrm{~min}$ or with wortmannin $(100 \mathrm{nmol} / \mathrm{l})$ for $30 \mathrm{~min}$. Cells were then incubated with $1 \mathrm{nmol} / \mathrm{l} \mathrm{C}$-peptide for $5 \mathrm{~min}$. The effect of phorbol dibutyrate (PDBU) is shown as a positive control. Results are percentages \pm SEM $(n=3)$ of control cells incubated with $1 \mathrm{nmol} / \mathrm{l}$ C-peptide alone. ${ }^{*} p<0.05$, relative to $\mathrm{C}$-peptide alone. c. Pertussis toxin inhibits C-peptide-induced ERK phosphorylation detected by immunoblotting in OK cells. OK cells were pre-treated with $100 \mathrm{ng} / \mathrm{ml}$ pertussis toxin for $18 \mathrm{~h}$ and then incubated with $1 \mathrm{nmol} / \mathrm{l} \mathrm{C}$-peptide for $5 \mathrm{~min}$. The blot is representative of three independent experiments response is very similar to that observed in the phosphorylated ERK immunoblots, with maximal ERK activity $(135 \pm 1 \%)$ relative to control being observed with $500 \mathrm{pmol} / \mathrm{l} \mathrm{C}$-peptide and declining thereafter. Scrambled C-peptide had no significant effect on ERK activity (Fig. 2a). To determine the role of $\mathrm{G \alpha}_{\mathrm{i} / \mathrm{o}}$ G-proteins in activation of ERK, cells were pre-incubated overnight with PTX, an agent that ADP-ribosylates and inhibits $\mathrm{G \alpha}_{\mathrm{i} / \mathrm{o}}$ proteins. Pre-treatment of the cells with PTX entirely blocked the activation of ERK induced by C-peptide (Fig. 2b). Similarly pre-treatment with the PKC inhibitor, bisindolylmaleimide (Ro-31-8220; $10 \mu \mathrm{mol} / 1,30 \mathrm{~min}$ ), also significantly attenuated C-peptide-induced ERK activity (Fig. 2b). Pre-treatment with the PI-3 kinase inhibitor wortmannin $(100 \mathrm{nmol} / \mathrm{l}, 30 \mathrm{~min})$ had no significant effects on C-peptide-induced ERK activity (Fig. 2b). PTX also abolished the ability of C-peptide to cause phosphorylation of ERK-1 and ERK-2 as detected by immunoblotting (Fig. 2c).

Effect of C-peptide on Akt phosphorylation. To investigate the effects of $\mathrm{C}$-peptide on Akt activation in $\mathrm{OK}$ cells, western blot analyses with Akt-S473-phosphospecific antibodies were performed. C-peptide-evoked Akt stimulation was time-dependent. Significant Akt phosphorylation was apparent as early as 1 minute, with maximal stimulation of Akt phosphorylation to $4.1 \pm 0.05$-fold over basal occurring after 5 minutes of exposure to C-peptide (Fig. 3). Robust, concentrationdependent activation of Akt by C-peptide, with a substantial activation of Akt by $100 \mathrm{pmol} / \mathrm{l} \mathrm{C}$-peptide, was also observed. Maximal phosphorylation of Akt to $2.5 \pm 0.03$-fold over the basal was observed with $5 \mathrm{nmol} / \mathrm{l} \mathrm{C}$-peptide. The total amount of Akt was not changed at any concentration of C-peptide tested (Fig. 3a, b). Akt activation was not stimulated by scrambled C-peptide (Fig. 3c).

To determine whether phosphorylation of Akt by Cpeptide was dependent on PI3-K activity, we examined the effect of the PI-3 kinase inhibitor wortmannin on Akt phosphorylation. We found that C-peptide-induced Akt phosphorylation was completely abolished by pretreatment of cells with wortmannin $100 \mathrm{nmol} / \mathrm{l}$ (Fig.3d).

Effect of C-peptide on intracellular $\mathrm{Ca}^{2+}$ concentration. Exposure of OK cells to $5 \mathrm{nmol} / \mathrm{l} \mathrm{C}$-peptide was accompanied by increases in $\left[\mathrm{Ca}^{2+}\right]_{\mathrm{i}}$. These increases varied between cells. In six independent experiments, about 100 cells were examined after exposure to C-peptide. Approximately $10 \%$ of all OK cells exhibited a robust increase in $\left[\mathrm{Ca}^{2+}\right]_{i}$, returning to basal levels within 1 min. Approximately $60 \%$ of cells responded to $\mathrm{C}$-peptide with a more modest increase in $\left[\mathrm{Ca}^{2+}\right]_{\mathrm{i}}$. A minority of cells showed no increase in $\left[\mathrm{Ca}^{2+}\right]_{i}$. Figure 4 depicts a representative field of cells viewed in real time by confocal microscopy. Figure $4 \mathrm{c}$ shows a graphical representation of the effects of 
a
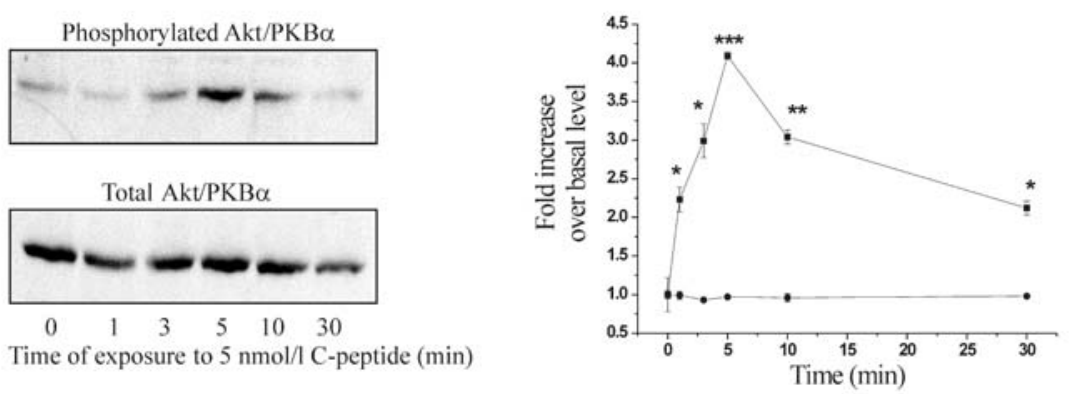

b

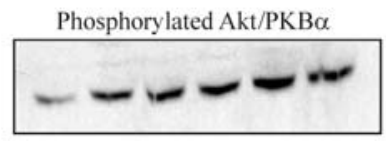

Total Akt/PKB $\alpha$

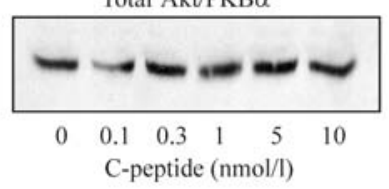

c

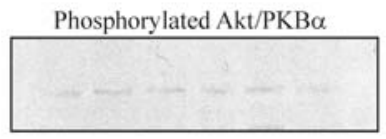

Total Akt/PKBc

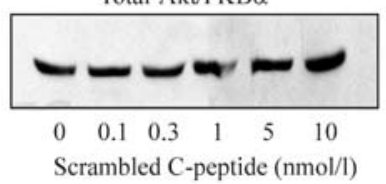

Fig. 3. Stimulation of Akt phosphorylation in opossum kidney (OK) cells by C-peptide but not by scrambled C-peptide. a. Time course of activation. Cells were treated with $5 \mathrm{nmol} / \mathrm{l}$ C-peptide for the indicated times and total Akt or phosphorylated Akt detected by immunoblotting. The left panel shows a representative blot. Phosphorylated bands were quantified and values expressed graphically (right panel). ${ }^{*} p<0.05,{ }^{*} p<0.01$, $* * * p<0.001$, relative to 0 minutes. b. Concentration response of activation. Cells were treated with the indicated concentrations of C-peptide for $5 \mathrm{~min}$ and total Akt or phosphorylated Akt detected by immunoblotting. The left panel shows a representative blot. Phosphorylated bands were quantified and values expressed graphically (right panel). ${ }^{*} p<0.05$, ${ }^{*} p<0.01$, $* * * p<0.001$, relative to control. c. Effect of scrambled C-peptide on Akt phosphorylation in OK cells. Cells were treated with the indicated concentrations of scrambled C-peptide for 5 min and total Akt or phosphorylated Akt detected by immunoblotting. A representative blot is shown. d. PI3-kinase inhibitor inhibits C-peptide-induced Akt/PKB $\alpha$ phosphorylation detected by immunoblotting in OK cells. Cells were pre-treated with $100 \mathrm{nmol} / \mathrm{l}$ wortmannin for $1 \mathrm{~h}$ and then incubated with $5 \mathrm{nmol} / \mathrm{l} \mathrm{C}$-peptide for $5 \mathrm{~min}$. The blot is representative of three independent experiments. Within the graphs $(\mathbf{a}, \mathbf{b})$ data are means \pm SEM $(n=3)$; squares represent phosphorylated Akt and circles total Akt

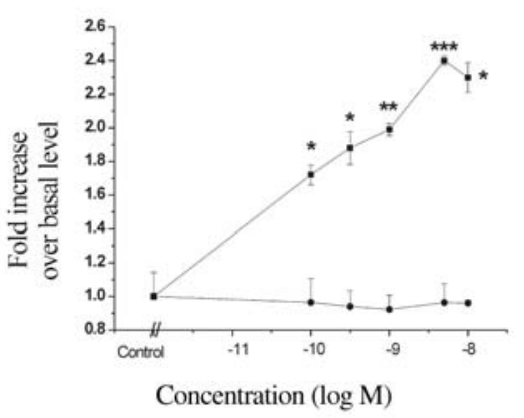

d

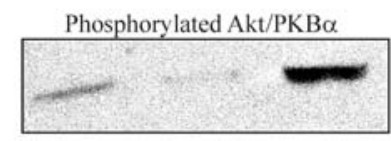

Total Akt/PKB $\alpha$

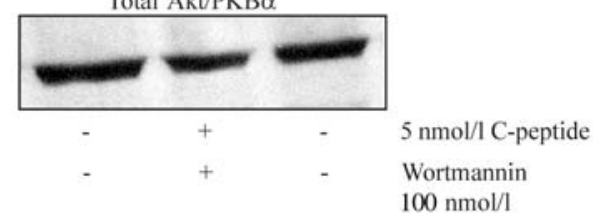

C-peptide on $\left[\mathrm{Ca}^{2+}\right]_{\mathrm{i}}$ as fold increases in fluorescence intensity compared to basal levels. Cell 1(Fig. 4c) exhibited an increase in fluorescence intensity of about 3.3-fold over basal, returning to basal within $1 \mathrm{~min}$. Cell 2 (Fig. 4c) shows a more modest increase in fluorescence intensity (about 1.1 over basal), while cell 3 (Fig.4c) did not demonstrate any increase in $\left[\mathrm{Ca}^{2+}\right]_{i}$. No cells demonstrated any increment in $\left[\mathrm{Ca}^{2+}\right]_{\mathrm{i}}$ after exposure to $5 \mathrm{nmol} / \mathrm{l}$ scrambled C-peptide.

Effect of C-peptide on activation of PKC isoforms. Using western blotting, we reliably detected the PKC isoforms $-\alpha,-\varepsilon,-\imath$ in OK cells (Fig. 5a). To examine the effects of C-peptide on PKC activity, we analysed $\mathrm{C}$-peptide-induced translocation of these PKC isoforms from a cell cytosolic compartment to a membrane compartment by cell fractionation. Control experiments showed that treatment of OK cells with $1 \mu \mathrm{mol} / \mathrm{l}$ phorbol myristate acetate (PMA) for $5 \mathrm{~min}$ increased the amounts of PKC- $\alpha$ in the membrane fraction, whilst decreasing it in the cytosol fraction. This confirmed that PKC translocation could be followed using this technique. Figure 5 depicts a repre- 

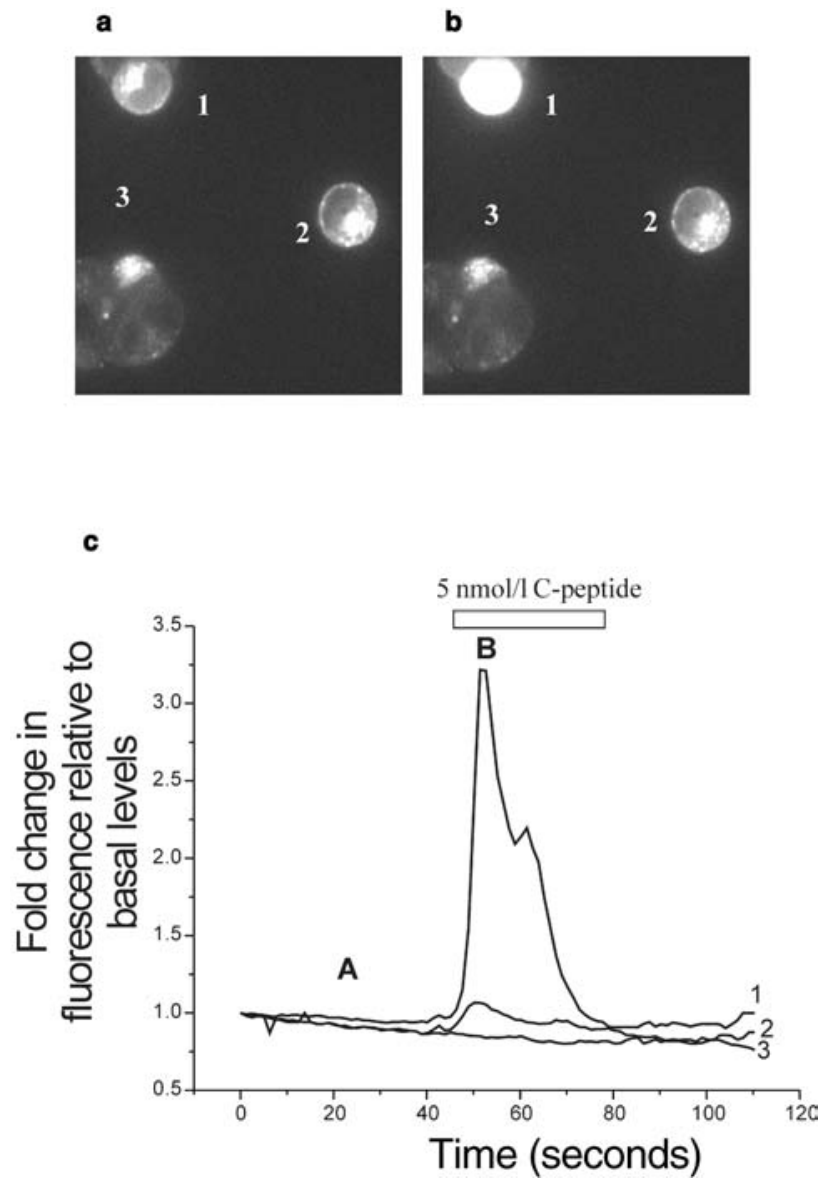

Fig. 4. $\left[\mathrm{Ca}^{2+}\right]_{\mathrm{i}}$ responses to $\mathrm{C}$-peptide in opossum kidney cells. Cells plated on coverslips and loaded with flu-3-AM were excited at $488 \mathrm{~nm}$ and imaged using a confocal microscope under non-stimulated conditions (a) or following stimulation with $5 \mathrm{nmol} / \mathrm{l} \mathrm{C}$-peptide in the perfusate (b). Changes in fluorescence in cell 1,2 and 3 in the field of view are represented graphically (c) as fold increases in fluorescence relative to basal levels. Image A was obtained at 20 seconds, image B at 55 seconds. The traces derived from cells 1,2 and 3 are numbered respectively. Data are representative of six experiments

sentative experiment, which shows that treatment of OK cells with $5 \mathrm{nmol} / \mathrm{l} \mathrm{C}$-peptide for $5 \mathrm{~min}$ resulted in a two-fold increase in the amount of PKC- $\alpha$ in the membrane fraction compared to the control cells, which had been subjected to a change of media alone (lacking C-peptide). In contrast, the amounts of PKC$\varepsilon$ and $-l$ isoforms remained unchanged in the membrane fraction after C-peptide stimulation, although membrane translocation of $\mathrm{PKC}-\varepsilon$ was seen after PMA treatment (Fig. 5a). Thus, C-peptide specifically translocates PKC- $\alpha$ in OK cells.

C-peptide may elicit its cellular effects by binding to a putative cell membrane receptor coupled to a PTX-sensitive G-protein [16, 17]. To determine whether C-peptide recruited PKC- $\alpha$ to the membrane through such a receptor, OK cells were treated with PTX $(100 \mathrm{ng} / \mathrm{ml})$ for $18 \mathrm{~h}$ before stimulation with $5 \mathrm{nmol} / \mathrm{l}$ C-peptide. PTX pre-treatment resulted in a

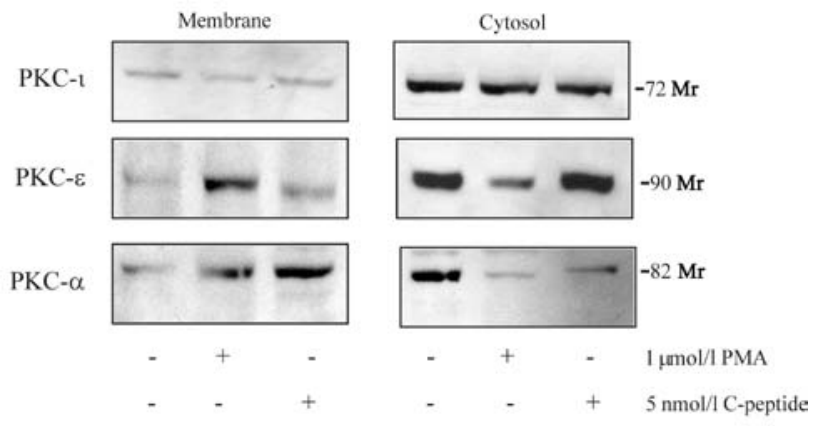

b

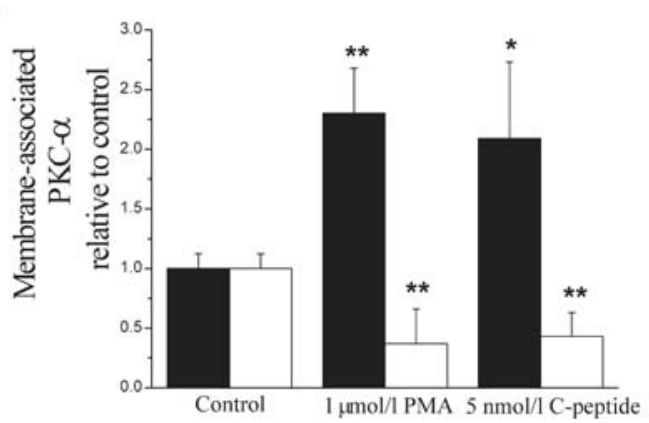

Fig. 5. Effect of C-peptide on PKC-1, $-\varepsilon$ and $-\alpha$ isoform translocation in opossum kidney cells. Serum-starved cells were treated with either $5 \mathrm{nmol} / \mathrm{l} \mathrm{C}$-peptide or $1 \mu \mathrm{mol} / \mathrm{l}$ phorbol myristate acetate (PMA) for $5 \mathrm{~min}$. Membrane and cytosol where prepared as described. a. PKC isoforms were detected by western blotting of membrane and cytosol fractions with isoform-specific anti-PKC- $-1,-\varepsilon$ and $-\alpha$ antibody. $b$. The amounts of PKC- $\alpha$ in membrane (black bars) and cytosolic (white bars) fractions were quantified using Scion Image analysis software and results are expressed relative to those of untreated control cells. Data are means \pm SEM, $n=5$. * $p<0.05, * * p<0.01$, relative to control

complete inhibition of C-peptide-induced PKC- $\alpha$ translocation (Fig. 6).

Since the PKC- $\alpha$ isoform is $\mathrm{Ca}^{2+}$-dependent, we examined whether the activation of PKC- $\alpha$ was dependent upon extracellular $\mathrm{Ca}^{2+}$. Cells were incubated with $\mathrm{Ca}^{2+}$-free Krebs Henseleit buffer for $1 \mathrm{~h}$ before exposure to C-peptide. As shown in Figure 6, C-peptide failed to translocate PKC- $\alpha$ in the absence of extracellular $\mathrm{Ca}^{2+}$.

Effects of C-peptide on the growth of OK cells. After demonstrating the ability of C-peptide to activate mitogenic signalling pathways in OK cells, we studied the effect of C-peptide on cell proliferation. As demonstrated in Figure 7a, incubation of OK cells with $\mathrm{C}$-peptide for $24 \mathrm{~h}$ resulted in an increase in $\left[{ }^{3} \mathrm{H}\right]$-thymidine incorporation. This increase was maximal at $5 \mathrm{nmol} / \mathrm{l} \mathrm{C}$-peptide (130 $\pm 3.5 \%$, compared to non-stimulated controls; $n=4)$. As a positive control, the effect of $10 \%$ FCS on proliferation of OK cells was studied and found to increase $\left[{ }^{3} \mathrm{H}\right]$-thymidine incorporation by 
a
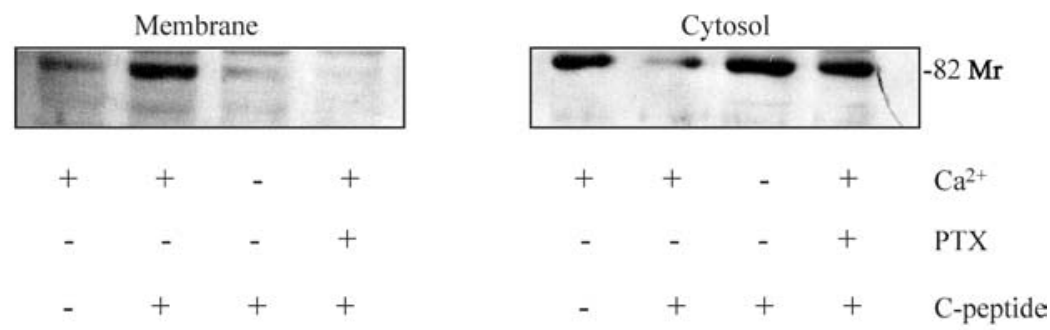

b

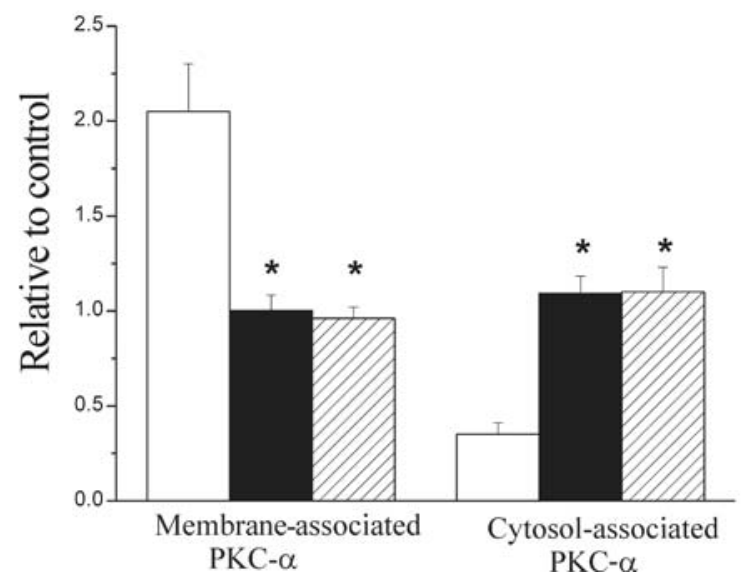

Fig. 6. PKC- $\alpha$ translocation is inhibited by pertussis toxin (PTX) and in $\mathrm{Ca}^{2+}$-free medium. Opossum kidney cells were pre-treated with $100 \mathrm{ng} / \mathrm{ml}$ PTX for $18 \mathrm{~h}$ or incubated in $\mathrm{Ca}^{2+}$ free Krebs buffer prior to stimulation with $5 \mathrm{nmol} / \mathrm{l} \mathrm{C}$-peptide for $5 \mathrm{~min}$. a. Membrane and cytosol were prepared and PKC- $\alpha$ was detected by western blotting. A representative immunoblot is depicted. b. The amount of PKC- $\alpha$ detected in immunoblots was quantified using Scion Image analysis software. The results are expressed relative to those of untreated control cells that were normalised to a value of 1 . White bars: responses of cells in $\mathrm{Ca}^{2+}$-containing Krebs buffer (control); black bars: responses of cells in $\mathrm{Ca}^{2+}$-free Krebs buffer; hatched bars: responses in cells pre-treated with PTX. Data are means \pm SEM, $n=4 .{ }^{*} p<0.05$ relative to controls

$370 \pm 8 \%$ (data not shown). Thus, C-peptide induced a significant increase in OK cell proliferation compared to non-stimulated controls, but this increase was modest compared to that achieved by $10 \%$ FCS. In some experiments cells were pre-treated either with PTX for $18 \mathrm{~h}$, or with wortmannin for $30 \mathrm{~min}$ before being exposed to C-peptide (Fig. 7b). Both PTX and wortmannin pre-treatments attenuated the C-peptideinduced proliferation of OK cells.

\section{Discussion}

Although C-peptide is important as a surrogate marker of insulin release and hence pancreatic beta cell func-

tion, it has for many years been regarded as biologically inert with no significant physiological purpose. In recent years a small number of publications have challenged this view and a growing body of data, derived from studies of animals and humans with diabetes, now supports the idea that $\mathrm{C}$-peptide plays a role in glucose homeostasis, in ameliorating the consequences of hyperglycaemia and in the abrogation of diabetic complications $[6,10,12]$. Despite this accumulating evidence, the concept of C-peptide as a bioactive molecule has yet to gain wide acceptance. Nonetheless, the observation that C-peptide can alter cell function suggests that, like insulin, it may exert endocrine actions and possess signalling activity. Our aim therefore was to establish a repertoire of cell signalling effects induced by $\mathrm{C}$-peptide in a relevant cell line derived from the kidney proximal tubule, a nephron region thought to play a central role in tubulointerstitial injury in diabetes [36, 37].

Our results demonstrate clear and unambiguous stimulation of a number of key intracellular signalling pathways by C-peptide, but not by its scrambled counterpart, in OK cells with distinct cell functional consequences. Using two different methods, we unequivocally demonstrated stimulation of ERK by typical physiological concentrations of C-peptide [38, 39, 40] in the mid-picomolar to low-nanomolar range. Furthermore, phosphorylation of Akt induced by C-peptide is indicative of PI 3-kinase activation. Although both of these phenomena demonstrate similar rapid 

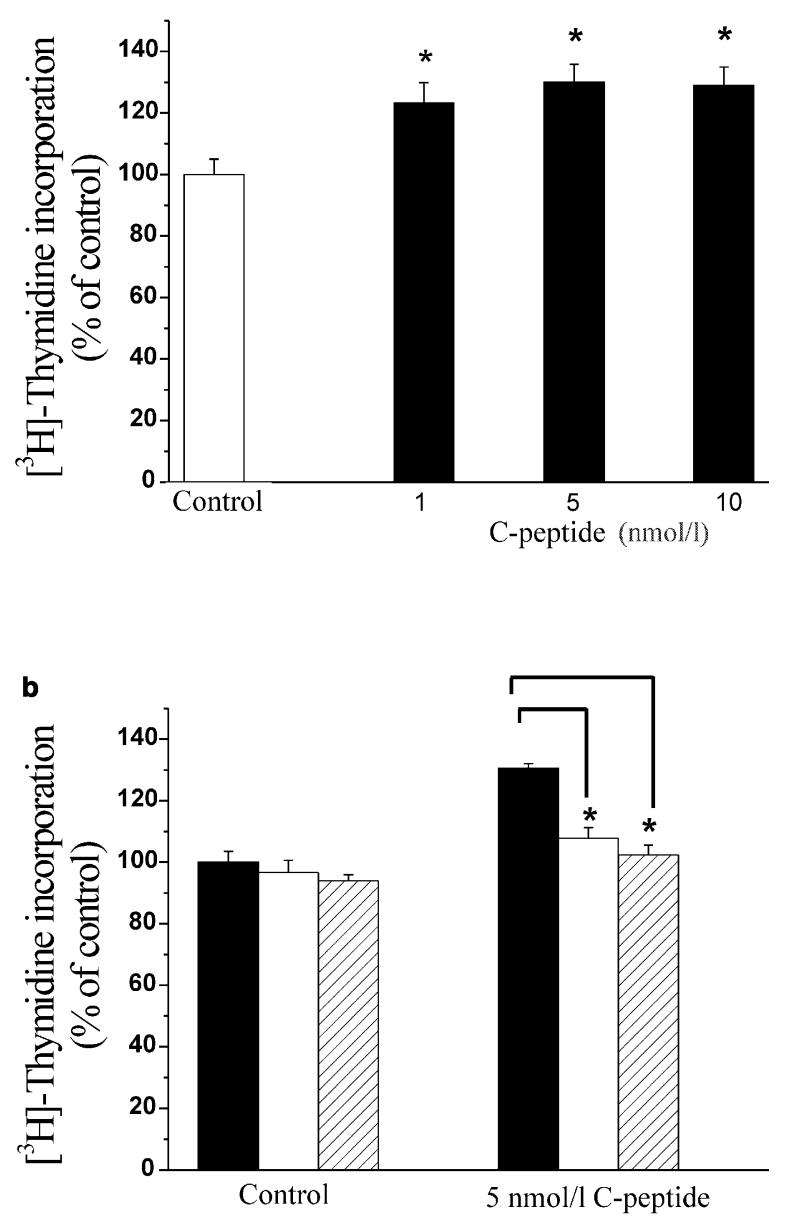

Fig. 7. C-peptide stimulates proliferation of opossum kidney (OK) cells. a. OK cells were stimulated with various concentrations of C-peptide in serum-free media for $24 \mathrm{~h}$ (black bars). The results are presented as percentages (means \pm SEM, $n=4$ ) of unstimulated control cells (white bars); $* p<0.05$, relative to control. b. OK cells were pre-treated with either $100 \mathrm{nmol} / \mathrm{l}$ wortmannin for $30 \mathrm{~min}$ or with $100 \mathrm{ng} / \mathrm{ml}$ pertussis toxin (PTX) for $18 \mathrm{~h}$, and then incubated in serum-free medium without (control) or with $5 \mathrm{nmol} / \mathrm{l} \mathrm{C}$-peptide. Black bars: no pre-treatment; white bars: pre-treatment with wortmannin; hatched bars: pre-treatment with PTX. The results are presented as percentages (means \pm SEM, $n=3$ ) of the unstimulated control cells; ${ }^{*} p<0.05$, relative to control cells (no C-peptide treatment)

kinetics of activation, C-peptide is a more potent activator of ERK than PI-3 kinase. Also the relationship between ERK stimulation and C-peptide concentration is described by a bell-shaped curve, whereas the relationship between C-peptide concentration and ERK stimulation is sigmoidal. There is little evidence that C-peptide signals via more than one receptor, and the explanation of these differences is unclear.

Consistent with the observations of others $[13,15]$, we observed C-peptide-evoked increases in $\left[\mathrm{Ca}^{2+}\right]_{\mathrm{i}}$. In our studies only a minority of cells showed a robust rise in $\left[\mathrm{Ca}^{2+}\right]_{i}$, the majority showing modest increases and approximately $10 \%$ not showing any response at all. Whilst such heterogeneity of response may reflect heterogeneity in the cell culture population, no such variability was seen in our earlier studies of lysophosphatidic acid-induced $\mathrm{Ca}^{2+}$ transients in this cell type [32]. In practical terms, however, this variability in the observed $\mathrm{Ca}^{2+}$ responses limited our ability to dissect the mechanisms underlying $\mathrm{C}$-peptide-induced changes in $\left[\mathrm{Ca}^{2+}\right]_{i}$.

Our observation of $\mathrm{Ca}^{2+}$-dependent membrane translocation of PKC- $\alpha$ supports the idea that C-peptide activates $\mathrm{Ca}^{2+}$ signalling in $\mathrm{OK}$ cells, providing evidence for the concept that $\mathrm{Ca}^{2+}$-dependent pathways play an important role in actions mediated by C-peptide [13, 15, 41]. Robust PKC- $\alpha$ translocation was also observed in response to $\mathrm{C}$-peptide at physiologically relevant low nanomolar concentrations. Abolition of this phenomenon in $\mathrm{Ca}^{2+}$-free medium and by PTX indicates that it is mediated via a GPCR and dependent on entry of $\mathrm{Ca}^{2+}$ into the cell, rather than its release from intracellular stores. The PKC isoforms $-\varepsilon$ and $-\mathrm{l}$ were detected by western blotting but did not translocate. Efendiev et al. [42] indicated that OK cells express all the PKC isoforms except $\gamma$. In the current study, we did not detect other PKC isoforms in $\mathrm{OK}$ cells, and in fact a detailed evaluation of PKC isoforms was not intended. These differences probably relate to problems of antibody specificity and consequent failure to detect opossum PKC isoforms.

A plasma membrane receptor for C-peptide has not yet been identified, and it has been suggested that non-receptor-mediated membrane interactions could explain C-peptide effects [43]. However, the inhibition, by PTX, of C-peptide-stimulated signalling in OK cells implicates a GPCR, coupled to either $\mathrm{G \alpha}_{\mathrm{i}}$ or $\mathrm{G} \alpha_{0}$, in the transduction of these events. Such observations are in agreement with studies demonstrating PTX-sensitive C-peptide binding to kidney cell membranes [18], and they provide strong support for the existence of a specific C-peptide receptor. Furthermore, the C-peptide concentrations that stimulated signalling in the current studies correlate well with the affinity of the previously described binding sites [18].

C-peptide-induced ERK activity via $\mathrm{G \alpha}_{\mathrm{i} / \mathrm{o}}$ coupling receptor suggests a possible involvement of $G \beta \gamma$. A common ERK stimulatory module involves activation of PI3-kinase by Ras, mediated via G $\beta \gamma$ subunits [44]. However, C-peptide-induced ERK activity was not affected by wortmannin, suggesting that PI3-kinase is not involved in this stimulation. The attenuation of ERK activity by pre-treatment with Ro-31-8820 suggests that C-peptide-induced ERK activity is dependent on PKC in OK cells as proposed by Kitamura et al. [17] for Swiss 3T3 fibroblasts.

Following our observation that C-peptide stimulated kinases with well-described roles in the regulation of growth, proliferation and cell survival [45, 46, 47], we wished to determine whether C-peptide was a functional mitogen in OK cells. Accordingly, physio- 
logical concentrations of C-peptide were found to stimulate $\mathrm{OK}$ cell proliferation in a manner that was dependent on PI 3-kinase activity and sensitive to PTX. Previous studies reported that similar concentrations of C-peptide are mitogenic for human neuroblastoma cells [48]. This latter finding is compatible with our present results and suggests that ERK is involved in C-peptide-induced cell proliferation. It is, however, difficult to interpret concentration dependency data in OK cells, because proximal tubular cells are active in peptide catabolism. Thus, after the obligate exposure of $\mathrm{OK}$ cells to $\mathrm{C}$-peptide for $24 \mathrm{~h}$ in $\left[{ }^{3} \mathrm{H}\right]$-thymidine incorporation studies, C-peptide concentrations in the culture medium may be considerably lower than those applied at the start of the experiment. Nevertheless, it is tempting to suggest that the absence of this mitogenic effect in diabetes may contribute to the hypertrophic renal growth abnormalities seen in diabetic nephropathy.

The salutary effects of C-peptide observed in patients with diabetes are not paralleled by similar observations in healthy individuals. Moreover, data on C-peptide binding suggest that under normal physiological conditions binding sites may be fully occupied. Thus, reduced C-peptide signalling may only become important in diabetic patients when levels fall or become undetectable. In this situation, one could speculate that balanced interactions between insulin, C-peptide and glucose signalling pathways may be disturbed, leading to the development of diabetic complications.

Some preliminary evidence of cross-talk between insulin and C-peptide has been found. Using L6 rat myoblasts, one group [49] demonstrated that C-peptide inhibits protein tyrosine phosphatase, with associated increases in phosphorylation of the insulin receptor and insulin receptor substrate-1. These findings in myoblasts were subsequently extended to show insulinomimetic C-peptide effects, manifest as induced phosphorylation of glycogen synthase kinase, ERK and p90Rsk [50]. No effect of C-peptide on phosphorylation of Akt was seen in that study, although C-peptide did increase phosphotyrosine-associated PI 3-kinase activity as measured by immune complex in vitro kinase assay. Some synergy was observed between C-peptide and insulin, but only at sub-maximal concentrations.

Taken together, the available data indicate important GPCR-mediated effects of C-peptide at the cellular level. These translate into vital effects on insulin action and glucose homeostasis, when measured at the whole-animal level. The cellular effects of C-peptide are not apparent in all cells investigated, but are clearly present in OK proximal tubular cells. Indeed, we have also demonstrated identical effects in primary cultures of human proximal tubular cells (data not shown). Further studies of the interaction between $\mathrm{C}$-peptide and insulin signalling and the effects of changes in prevailing glucose concentrations will enhance our understanding of glucose metabolism and the pathogenesis of diabetic complications, thereby providing a new impetus for the investigation of C-peptide as a therapeutic agent in the treatment of diabetes mellitus.

Acknowledgements. This work was supported in part by Wellcome Trust grant no. 061050, and by a Wellcome Trust Vacation Scholarship awarded to Eve Royal. We wish to thank Nouf Al-Rasheed for valuable assistance with the PKC translocation studies.

\section{References}

1. Steiner DF, Cunningham D, Spigelman L, Aten B (1967) Insulin biosynthesis: evidence for precursor. Science 157:697-700

2. Rubenstein A, Clark J, Melani F, Steiner D (1969) Secretion of proinsulin C-peptide by pancreatic beta cells and its circulation in blood. Nature 224:697-699

3. Steiner DF (1978) On the role of the proinsulin C-peptide. Diabetes 27 [Suppl 1]:145-148

4. Hoogwerf BJ, Bantle JP, Genslen HE (1986) Infusion of synthetic human C-peptide does not affect plasma glucose, serum insulin, or plasma glucagon in healthy subjects. Metabolism 35:122-125

5. Kitabchi AE (1977) Proinsulin and C-peptide: a review. Metabolism 26:547-587

6. Wahren J, Ekberg K, Johansson J et al. (2000) Role of C-peptide in human physiology. Am Physiol Endocrinol Metab 278:E759-E768

7. Johansson BL, Sjoberg S, Wahren J (1992) The influence of human C-peptide on renal function and glucose utilization in the type I (insulin-dependent) diabetic patients. Diabetologia 35:121-128

8. Johansson BL, Kernell A, Sjoberg S, Wahren J (1993) Influence of combined $\mathrm{C}$-peptide and insulin administration on renal function and metabolic control in diabetes type 1. J Clin Endocrinol Metab 77:976-981

9. Johansson BL, Borg K, Fernqvist-Forbes E, Odergren T, Remahl S, Wahren J (1996) C-peptide improves autonomic nerve function in IDDM patients. Diabetologia 39:687695

10. Ekberg K, Brismar T, Johansson BL, Lindstrom P, Wahren J (2003) Amelioration of sensory nerve dysfunction by C-peptide in patients with type 1 diabetes. Diabetes 52:536-541

11. Johansson BL, Wahren J, Pernow J (2003) C-peptide increases forearm blood flow in patients with type 1 diabetes via a nitric oxide-dependent mechanism. Am J Physiol Endocrinol Metab 285:E864-E870

12. Hansen A, Johansson BL, Wahren J, Von Bibra H (2002) C-peptide exerts beneficial effects on myocardial blood function in patients with type 1 diabetes. Diabetes 51:30773082

13. Ohtomo Y, Aperia A, Sahlgren B, Johansson BL, Wahren J (1996) C-peptide stimulates rat renal tubular $\mathrm{Na}^{+}, \mathrm{K}^{+}$ATPase activity in synergism with neuropeptide Y. Diabetologia 39:199-205

14. Ohtomo Y, Bergman T, Johansson BL, Jornvall H, Wahren J (1998) Differential effects of proinsulin C-peptide on $\mathrm{Na}^{+}, \mathrm{K}^{+}$-ATPase activity of renal tubule segments. Diabetologia 41:287-291 
15. Shafqat J, Juntti-Berggren L, Zhong Z et al. (2002) Proinsulin C-peptide and its analogues induce intracellular $\mathrm{Ca}^{+2}$ increase in human renal tubular cells. Cell Mol Life Sci 59:1185-1189

16. Tismaratos M, Roger F, Chabardes D et al. (2003) C-peptide stimulates $\mathrm{Na}^{+}-\mathrm{K}^{+}$-ATPase activity via $\mathrm{PKC}$ alpha in rat medullary thick ascending limb. Diabetologia 46:124-131

17. Kitamura T, Kimura K, Jung BD et al. (2001) Proinsulin C-peptide rapidly stimulates mitogen-activated protein kinases in Swiss3T3 fibroblasts: requirement of protein kinase $\mathrm{C}$, phosphoinositide3-kinase and pertussis toxinsensitive G-protein. Biochem J 355:123-129

18. Rigler R, Pramanik A, Jonasson P et al. (1999) Specific binding of proinsulin C-peptide to human cell membranes. Proc Natl Acad Sci USA 96:13318-13323

19. Pramanik A, Ekberg K, Zhong Z et al. (2001) C-peptide binding to human cell membranes: importance of Glu27. Biochem Biophys Res Commun 284:94-98

20. Ziyadeh FN (1993) The extracellular matrix in diabetic nephropathy. Am J Kidney Dis 22:736-744

21. Mogensen CE, Andersen MJ (1973) Increased kidney size and glomerular filtration rate in early juvenile diabetes. Diabetes 22:706-712

22. Seyer-Hansen K (1976) Renal hypertrophy in streptozotocin-diabetic rats. Clin Sci Mol Med 51:551-555

23. Ritz E, Stefanski A (1996) Diabetic nephropathy in type II diabetes. Am J Kidney Dis 27:167-197

24. Ibrahim HI, Hostetter TH (1997) Diabetic nephropathy. J Am Soc Nephrol 8:487-493

25. Wirta OR, Pasternack AI (1995) Glomerular filtration rate and kidney size in type 2 (non-insulin-dependent) diabetes mellitus. Clin Nephrol 44:1-7

26. Derubertis FR, Craven PA (1994) Activation of protein kinase $\mathrm{C}$ in glomerular cells in diabetes: mechanism and potential links to the pathogenesis of diabetic glomerulopathy. Diabetes 43:1-8

27. Craven PA, Patterson MC, Derubertis FR (1988) Role of enhanced arachidonate availability through the phospholipase $A_{2}$ pathway in the mediation of increased prostaglandin synthesis by glomeruli from diabetic rats. Diabetes 37:429-435

28. Ziyadeh FN, Fumo P, Rodenberger CH, Kuncio GS, Neilson EG (1995) Role of protein kinase C and cyclic AMP/protein kinase A in high glucose-stimulated transcriptional activation of collagen $\alpha 1$ (IV) in glomerular mesangial cells. J Diabetes Complications 9:255-261

29. Haneda M, Araki S, Togawa M, Sugimoto T, Isono M, Kikkawa R (1997) Mitogen-activated protein kinase cascade is activated in glomeruli of diabetic rats and glomerular mesangial cells cultured under high glucose conditions. Diabetes 46:847-853

30. Koyama H, Goodpasture C, Miller M, Teplitl L, Riggs AD (1978) Establishment and characterization of a cell line from the American opossum (Didelphys virginiana). In Vitro 14:239-246

31. Pollock AS, Warnock DG, Strewler G (1986) Parathyroid hormone inhibition of $\mathrm{Na}^{+}-\mathrm{H}^{+}$antiporter activity in cultured renal cell line. Am J Physiol 250:F217-F225

32. Dixon R, Young K, Brunskill NJ (1999) Lysophosphatidic acid-induced calcium mobilization and proliferation in kidney proximal tubular cells. Am J Physiol 276:F191-F198
33. Brunskill NJ, Cockcroft N, Nahorski S, Walls J (1996) Albumin endocytosis is regulated by heterotrimeric GTPbinding protein $\mathrm{G \alpha}_{\mathrm{i}-3}$ in opossum kidney cells. Am J Physiol 271:F356-F364

34. Dixon RJ, Brunskill NJ (1999) Lysophosphatidic acidinduced proliferation in opossum kidney proximal tubular cells: Role of PI3-kinase and ERK. Kidney Int 56:20642075

35. Willars GB, Challiss RAJ, Stuart JA, Nahorski SR (1996) Contrasting effects of phorbol ester and agonist-mediated activation of protein kinase $\mathrm{C}$ on phosphoinositide and $\mathrm{Ca}^{2+}$ signalling in a human neuroblastoma. Biochem $\mathrm{J}$ 316:905-913

36. Wolf G, Ziyadeh FN (1999) Molecular mechanism of diabetic renal hypertrophy. Kidney Int 56:393-405

37. Phillips AO, Steadman R (2002) Diabetic nephropathy: the central role of renal proximal tubular cells in tubulointerstitial injury. Histol Histopathol 17:247-252

38. Dreyer M, Matthaei S, Kuhnau J, Rudiger HW (1986) Prolonged plasma half-life of insulin in patients with a genetic defect of high affinity binding sites. Horm Metab Res 18:247-249

39. Horwitz DL, Starr JI, Mako ME, Blackard WG, Rubenstein AH (1975) Proinsulin, insulin and C-peptide concentrations in human portal and peripheral blood. J Clin Invest 55:1278-1283

40. Faber OK, Hagen C, Binder C et al. (1978) Kinetics of human connecting peptide in normal and diabetic subjects. J Clin Invest 62:197-203

41. Johansson J, Ekberg K, Shafqat J et al. (2002) Breakthroughs and views: molecular effects of proinsulin C-peptide. Biochem Biophys Res Commun 295:1035-1040

42. Efendiev R, Bertorello AM, Pedemonte CH (1999) PKC- $\beta$ and $\mathrm{PKC}-\zeta$ mediate opposing effects on proximal tubule $\mathrm{Na}^{+}, \mathrm{K}^{+}$-ATPase activity. FEBS Lett 456:45-48

43. Ido Y, Vindigni A, Chang K et al. (1997) Prevention of vascular and renal dysfunction in diabetic rats by C-peptide. Science 277:563-566

44. Crespo P, Xu N, Simonds WF, Gutkind JS (1994) Rasdependent activation of MAP kinase pathway mediated by G-protein $\beta \gamma$ subunits. Nature 369:418-420

45. Hagemann C, Blank JL (2001) The ups and downs of MEK kinase interactions. Cell Signal 13:863-875

46. Bucher K (2000) The role of protein kinase C in the regulation of cell growth and in signalling to the cell nucleus. J Cancer Res Clin Oncol 126:1-11

47. Marte BM, Downward J (2001) PKB/Akt: connecting phosphoinositide 3-kinase to cell survival and beyond. Trends Biochem Sci 22:355-358

48. Li ZG, Zhang W, Sima AA (2003) C-peptide enhances insulin-mediated cell growth and protection against high glucose-induced apoptosis in SY5Y cells. Diabetes Metab Res Rev 19:375-385

49. Li ZG, Qiang X, Sima AA, Grunberger G (1997) C-peptide attenuates protein tyrosine phosphatase activity and enhances glycogen synthesis in L6 myoblasts. Biochem Biophys Res Commun 280:615-619

50. Grunberger G, Qiang X, Li Z et al. (2001) Molecular basis for the insulinomimetic effects of C-peptide. Diabetologia 44:1247-1257 